\title{
Skin Diseases and Sexually Transmitted Infections among Patients with HIV infection/AIDS referred at the City Institute for Skin and Venereal Diseases in Belgrade: a Case Series of 38 Patients
}

\author{
Milan BJEKIĆ ${ }^{1}$, Sandra ŠIPETIĆ ${ }^{2}$ \\ ${ }^{1}$ City Institute for Skin and Venereal Diseases, Belgrade, Serbia \\ ${ }^{2}$ Institute of Epidemiology, School of Medicine, University of Belgrade, Serbia \\ ${ }^{*}$ Correspondence: Milan Bjekić, E-mail: milinkovski@gmail.com
}

\author{
UDC 616.5: [616.988:578.828 \\ UDC 616.5:[616.988:578.828
}

\begin{abstract}
Human immunodeficiency virus (HIV) infection may be associated with a wide spectrum of dermatological disorders. This study reports the prevalence of dermatologic diseases and sexually transmitted infections among 38 HIV-infected adults who consecutively sought treatment at the City Institute for Skin and Venereal Diseases in Belgrade. Patients were referred by their primary HIV providers between January 2011 and June 2012 . More than $80 \%$ of patients were men who have sex with men. The most prevalent diseases were anogenital warts (36.8\%) and syphilis (34.2\%), followed by folliculitis and dermatophyte infections $(7.9 \%$ each). Thirty-four patients $(89.5 \%)$ were on highly active antiretroviral therapy (HAART) before the first visit to the dermatologist. Although, the pattern of skin disorders was consistent with literature data, high prevalence of sexually transmitted infections among our patients was rather peculiar. These facts point to the need for education of sexually active persons with HIV about the consequences of sexually transmitted infections, risks of transmission of drug resistant HIV strains, as well as safe sex practice and consistent condom use.
\end{abstract}

\section{Key words}

HIV; Skin Diseases; Sexually Transmitted Diseases; Risk Factors; Acquired Immunodeficiency Syndrome

$\mathrm{D}^{\mathrm{i}}$ isorders of the skin occur throughout the course of HIV infection affecting more than $90 \%$ of HIV-infected patients at some time (1,2). Even before the causative agent was identified, skin involvement in AIDS (eng. acquired immunodeficiency syndrome) has been appreciated in: establishing criteria for diagnosis and staging, as well as prognostic significance of some complications. As the infection progresses and diseases develop, the number of patients with mucocutaneous complications as well as the number of manifestations in any one patient increases (3). Dermatological manifestations in HIV patients are often more atypical than in HIV-negative patients (4). Not only the incidence, but also the severity of common dermatoses, for example, seborrhoeic dermatitis, herpes simplex, mollusca contagiosum, is increased correlating in many cases with the absolute numbers of $\mathrm{CD} 4+\mathrm{T}$ cells $(3,5)$.
The administration of highly active antiretroviral therapy (HAART) has been highly beneficial to patients with HIV-associated skin diseases, but on the other side, in many instances the skin has been affected by side effects of these drugs and manifestations of the immune reconstitution inflammatory syndrome/immune reconstitution disease (IRIS/IRD). Thus, HAART has altered clinical presentations of many skin diseases (6). Moreover, since the introduction of HAART, sexually transmitted infections have been increasing among HIV-infected homosexual men $(7,8)$.

According to the available data and routine surveillance, HIV infection in the Republic of Serbia has been well controlled. In the period of 2010 - 2011, there were 275 newly diagnosed HIV cases, 103 AIDS cases and 57 AIDS-related deaths reported to the Institute of Public Health of Serbia (Figures 1, 2, 3) (9). 


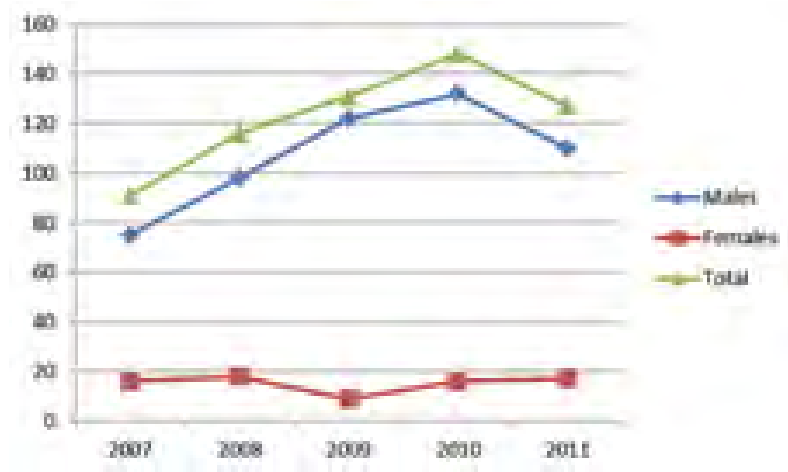

Figure 1. Number of newly diagnosed HIV cases, $2007-2011$

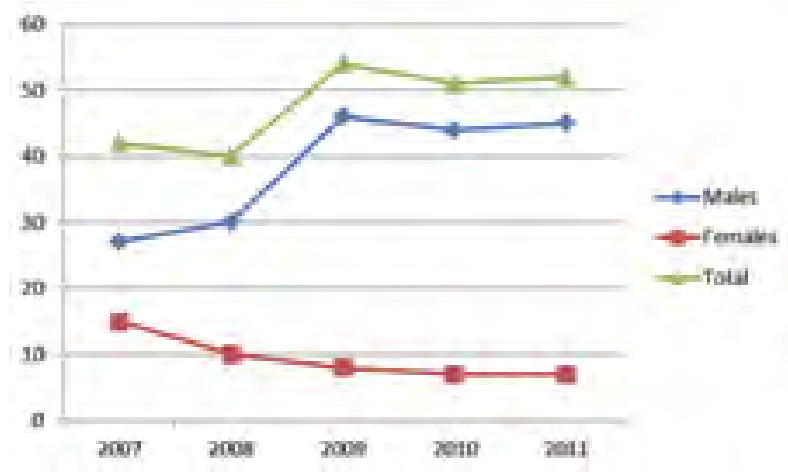

Figure 2. Number of AIDS cases, 2007 - 2011

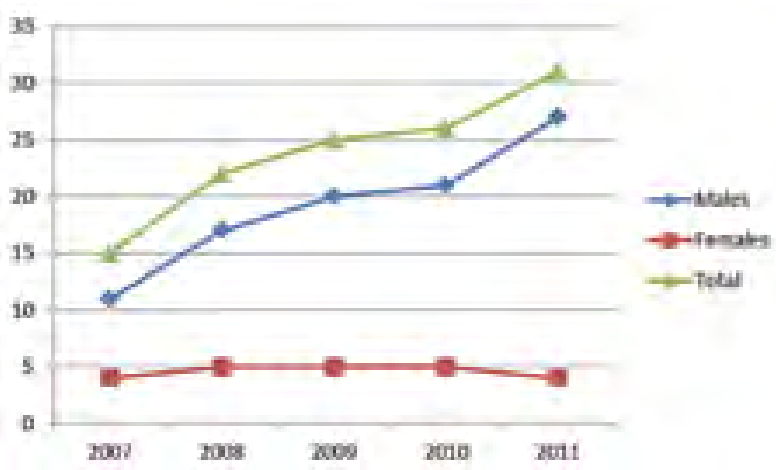

Figure 3. Number of AIDS-related deaths, 2007 - 2011

The purpose of this study was to investigate dermatologic diseases and sexually transmitted infections (STIs) among HIV-infected adults who sought treatment at the City Institute for Skin and Venereal Diseases in Belgrade.

\section{Patients and Methods}

The study included all patients referred to the City Institute for Skin and Venereal Diseases in Belgrade, by primary HIV providers, in the period between January 2011 and June 2012. One dermatologist examined and interviewed all HIV-infected patients. All diagnoses were based on patients' history and

Table 1. Demographic characteristics of 38 HIV-infected patients treated at the City Institute for Skin and Venereal Diseases in Belgrade

\begin{tabular}{ccc} 
Patients & $\mathbf{N}$ & $\mathbf{( \% )}$ \\
Age (years) & & \\
\hline $21-30$ & 9 & 23.7 \\
\hline $31-40$ & 19 & 50.0 \\
\hline $41-50$ & 4 & 10.5 \\
\hline $51-60$ & 6 & 15.8 \\
\hline Gender & 34 & 89.5 \\
\hline Male & 3 & 2.9 \\
\hline Female & 1 & \\
\hline Transgender & 34 & \\
\hline
\end{tabular}

$\mathrm{N}$ - number of patients 
physical examination and confirmed by laboratory tests if necessary. Data on basic demographic characteristics, as well as laboratory and other clinical results were retrospectively collected from patients' records. Unfortunately, data on CD $4+\mathrm{T}$ cell counts were not available.

\section{Results}

From January 2011 to June 2012, a total of 38 HIVinfected cases were referred to the City Institute for Skin and Venereal Diseases in Belgrade. Of 38 patients, there were $34(89.5 \%)$ males, $3(7.9 \%)$ females and one patient was transgender. Their average age was 37 years (range 22 - 59) (Table 1). Regarding sexual orientation, $31(81.6 \%)$ patients were homosexual, two were bisexual and 5 were heterosexual (Table 2). Thirty-four patients $(89.5 \%)$ were on HAART before the first visit to the dermatologist (Table 3).
All skin and venereal diseases diagnosed in our patients were ranked by prevalence (Table 4). The most prevalent diseases were anogenital warts $(36.8 \%)$ and syphilis (34.2\%). The next most common conditions were folliculitis (10.5\%), common warts and dermatophyte infections (7.9\%, each). The prevalence of molluscum contagiosum, seborrheic dermatitis, genital herpes, epidermoid cysts, gonorrhea and herpes zoster were $5.2 \%$, each.

\section{Discussion}

Diseases of the skin and mucous membranes were among the first recognized clinical manifestations of AIDS. Mollusca contagiosum, oral hairy leukoplakia, oral candidiasis, chronic ulcerating herpes simplex and Kaposi's sarcoma are strongly associated with advanced immunodeficiency (2). Effects that HIV infection may have on some skin conditions, for

Table 2. Sexual orientation of 38 HIV-infected patients treated at the City Institute for Skin and Venereal Diseases in Belgrade

\begin{tabular}{ccc} 
Patients & $\mathbf{N}$ & $\mathbf{( \% )}$ \\
Homosexual & 31 & 81.6 \\
\hline Bisexual & 2 & 5.2 \\
\hline Heterosexual & 5 & 13.2 \\
\hline
\end{tabular}

$\mathrm{N}$ - number of patients

Table 3. Number of dermatovenereologic diagnoses per patient among $38 \mathrm{HIV-infected} \mathrm{patients} \mathrm{treated} \mathrm{at} \mathrm{the}$ City Institute for Skin and Venereal Diseases in Belgrade

\begin{tabular}{ccc} 
Patients & $\mathbf{N}$ & $\mathbf{( \% )}$ \\
Initiated HAART & 34 & 89.5 \\
\hline Number of diagnoses & & \\
\hline one & 27 & 71.0 \\
\hline two & 5 & 13.2 \\
\hline three & 6 & 15.8 \\
\hline
\end{tabular}

$\mathrm{N}$ - number of patients; HAART - highly active retroviral therapy 
Table 4. The prevalence of dermatovenereologic diseases in 38 HIV-infected patients

\begin{tabular}{|c|c|c|}
\hline Diseases & $\mathbf{N}$ & Prevalence (\%) \\
\hline Anogenital warts & 14 & 36.8 \\
\hline Syphilis & 13 & 34.2 \\
\hline Folliculitis & 4 & 10.5 \\
\hline Common warts & 3 & 7.9 \\
\hline Dermatophyte infections & 3 & 7.9 \\
\hline Molluscum contagiosum & 2 & 5.2 \\
\hline Seborrhoeic dermatitis & 2 & 5.2 \\
\hline Genital Herpes & 2 & 5.2 \\
\hline Epidermoid cyst & 2 & 5.2 \\
\hline Gonorrhea & 2 & 5.2 \\
\hline Herpes zoster & 2 & 5.2 \\
\hline Erythrasma & 1 & 2.6 \\
\hline Onychomycosis & 1 & 2.6 \\
\hline Pityriasis versicolor & 1 & 2.6 \\
\hline Alopecia areata & 1 & 2.6 \\
\hline Androgenetic alopecia & 1 & 2.6 \\
\hline
\end{tabular}

example, psoriasis and leprosy, are less clarified. Over the past decade, HAART has dramatically altered the natural history of HIV infection, induced immune recovery, and decreased cutaneous manifestations of HIV infection $(6,10,11)$.

The majority of our patients have sought treatment for suspected STIs. The most prevalent were anogenital warts and syphilis, but gonorrhea and genital herpes were diagnosed as well. In this study more than $80 \%$ of patients were men who have sex with men (MSM). Moreover, in regard to HIV transmission among newly diagnosed HIV infected persons registered in Serbia in the period from 2002 2010, there was a clear increasing trend among MSM: $57 \%$ of all reported HIV cases in 2010 versus $26 \%$ in 2002 (9). Recent studies have shown an increase in sexually transmitted infections among HIV-positive homosexual men $(7,12)$. In an outbreak of early syphilis registered at the City Institute for Skin and Venereal Diseases in Belgrade during the period from 2010 to 2012 , of all patients, $76.5 \%$ were men who have sex with men (13). 
In this study, $38.6 \%$ of patients had anogenital warts. In the study of Zancarano et al., anogenital warts (condyloma acuminatum) were the second most common dermatological condition in HIV infected patients with a prevalence of $11.5 \%$ (6). Human papillomavirus (HPV) prevalence and symptoms tend to increase with disease progression, and anal cancer is associated with HPV infection and receptive anal intercourse. However, it is more common in HIVpositive than in HIV-negative homosexual men [14]. These facts point to the importance of preventive cytological screening for anal lesions to reduce the burden of morbidity and mortality from anal cancer.

Syphilis was diagnosed in $1 / 3$ of our patients and all of them were homosexuals. Several worldwide studies have reported syphilis outbreaks among MSM $(15,16,17)$. The patients in our study had atypical presentations with multiple ulcers that are usually associated with HIV coinfection (18). Although they were aware of infection, patients reported recent highrisk behavior. These data indicate that HIV-infected patients with syphilis may be among the most important transmitters of HIV infection due to biologic effects of genital ulcerations, and aggravation due to continued risky behavior. Folliculitis was the next most prevalent skin disorder $(10.5 \%)$ in our patients, which is in accordance with other studies where the prevalence ranged between $8 \%$ and $18 \%(6,19)$.

The most common skin diseases diagnosed in our patients were also reported in several other studies. According to Zancarano et al., the prevalence of dermatophyte infection of $7.1 \%$ was similar with our results, while prevalences of seborrheic dermatitis and skin xerosis were $10.6 \%$ and $9.7 \%$, respectively (6). In the study conducted in Bangkok, among 120 patients infected with HIV, the most prevalent skin disorder was xerosis (73.3\%), followed by oral candidiasis (54.2\%) and seborrhoic dermatitis (46.7\%) (20). In a study of Kumarasamy et al., the most frequent diagnoses in HIV infected patients were dermatophytosis, papular pruritic dermatitis, alopecia and herpes zoster (4).

Although the pattern of skin disorders was comparable to previous reports, there was a significantly higher prevalence of STIs in our patients. According to Kalichman et al, persons with HIV/AIDS report high rates of morbidity and symptoms of STIs (21).
In Western Europe, STIs have been disproportionately diagnosed among HIV-positive MSM in the postHAART era (12). It may be explained by an increase in high risk behavior due to treatment optimism, growing population of sexually active HIV-positive MSM and HIV-positive homosexual men unaware of their HIV status.

Our findings together with others, highlight the need for education of sexually active persons with HIV about consequences of STIs, as well as about risks of transmission of drug resistant HIV strains, safe sex practice and consistent condom use. Furthermore, routine testing for STIs and anal cytology screening should be encouraged and offered to HIV-positive MSM.

\section{Acknowledgement}

This study was supported by the Ministry for Science and Technology of the Republic of Serbia, Contract No. 175042 (2011-2014).

\section{References}

1. Coldiron BM, Bergstresser PR. Prevalence and clinical spectrum of skin disease in patients infected with human immunodeficiency virus. Arch Dermatol 1989;125:357-61.

2. Tschachler E, Bergstresser PR, Stingl G. HIV-related skin diseases. Lancet 1996;348:659-63.

3. Bunker CB, Gotch F. HIV and the skin. In: Burns T, Breathnach S, Cox N, Griffiths C, editors. Rook's textbook of dermatology. $6^{\text {th }}$ ed. Oxford: Blackwell Publishing Ltd; 2010. p. 35.1-47.

4. Kumarasamy N, Solomon S, Madhivanan P, Ravikumar B, Thyagarajan SP, Yesudian P. Dermatologic manifestations among human immunodeficiency virus patient in south India. Int J Dermatol 2000;39:192-5.

5. Jensen BL, WEismann K, Sindrup JH, Søndergaard J, Schmidt $\mathrm{K}$. Incidence and prognostic significance of skin disease in patients with HIV/AIDS: a 5-year observational study. Acta Derm Venereol 2000;80:140-3.

6. Zancanaro PC, McGirt LY, Mamelak AJ, Nguyen RH, Martins CR. Cutaneous manifestations of HIV in the era of highly active antiretroviral therapy: an institutional urban clinic experience. J Am Acad Dermatol 2006;54:581-8.

7. Stolte IG, Dukers NH, de Wit JB, Fennema JS, Coutinho RA. Increase in sexually transmitted infections among homosexual men in Amsterdam in relation to HAART. Sex Transm Infect 2001;77:184-6.

8. Fenton KA, Lowndes CM. Recent trends in the epidemiology of sexually transmitted infections in the European Union. Sex Transm Infect 2004;80:255-63.

9. Institute of Public Health of Serbia "Dr Milan Jovanovic Batut". Center for disease control and prevention: report of infectious diseases in the Republic of Serbia in 2011. Belgrade: Institute 
of Public Health of Serbia "Dr Milan Jovanovic Batut”; 2012. p. 39-50.

10. Domingo P, Torres OH, Ris J, Vazquez G. Herpes zoster as an immune reconstitution disease after initiation of combination antiretroviral therapy in patients with human immunodeficiency virus type-1 infection. Am J Med 2001;110:605-9.

11. Holmes RB, Martins C, Horn T. The histopathology of folliculitis in HIV-infected patients. J Cutan Pathol 2002;29:93-5.

12. Dougan S, Evans BG, Elford J. Sexually transmitted infections in Western Europe among HIV-positive men who have sex with men. Sex Transm Dis 2007;34:783-90.

13. Bjekić M, Šipetić S. An outbreak of early syphilis in patients registered at the City institute for skin and venereal diseases. Serb J Dermatol Venereol 2013;(2):65-71.

14. Palefsky JM, Holly EA, Ralston ML, Jay N. Prevalence and risk factors for human papillomavirus infection of the anal canal in human immunodeficiency virus (HIV)-positive and HIV-negative homosexual men. J Infect Dis. 1998;177:361-7.

15. Centers for Disease Control and Prevention. Outbreak of syphilis among men who have sex with men - Southern California, 2000. MMWR Morb Mortal Wkly Rep 2001;50:117-20.

16. Velicko I, Arneborn M, Blaxhult A. Syphilis epidemiology in Sweden: re-emergence since 2000 primarily due to spread among men who have sex with men. Euro Surveill
2008;13(50). [cited 2013 Nov 3]. Available from: http://www. eurosurveillance.org/ViewArticle.aspx? ArticleId=19063.

17. Giuliani M, Palamara G, Latini A, Maini A, Di Carlo A. Evidence of an outbreak of syphilis among men who have sex with men in Rome. Arch Dermatol 2005;141:100-1.

18. Lynn WA, Lightman S. Syphilis and HIV: a dangerous combination. Lancet Infect Dis 2004;4:456-66.

19. Calista D, Morri M, Stagno A, Boschini A. Changing morbidity of cutaneous diseases in patients with HIV after the introduction of highly active antiretroviral therapy including a protease inhibitor. Am J Clin Dermatol 2002;3:59-62.

20. Wiwanitkit V. Prevalence of dermatological disorders in Thai HIV-infected patients correlated with different CD4 lymphocyte count statuses: a note on 120 cases. Int J Dermatol 2004; $43: 265-8$.

21. Kalichman SC, Rompa D, Cage M. Sexually transmitted infections among HIV seropositive men and women. Sex Transm Infect 2000;76:350-4.

\section{Abbreviations}

HIV - human immunodeficiency virus AIDS - acquired immunodeficiency syndrome HAART - highly active antiretroviral therapy STIs - sexually transmitted infections MSM - men who have sex with men

\section{Dermatoze i seksualno prenosive infekcije kod pacijenata sa HIV invekcijom/AIDS koji su pregledani u Gradskom zavodu za kožne i venerične bolesti u Beogradu: serija od 38 pacijenata}

\section{Sažetak}

Uvod: U toku infekcije virusom humane imunodeficijencije (HIV - eng. human immunodeficiency virus) i kod pacijenata sa sindromom stečene imunodeficijencije (AIDS - engl. acquired immunodeficiency syndrome), mogu se javiti različita dermatološka oboljenja.

Cilj: Cilj rada bio je da se utvrdi prevalencija i vrsta kožnih i polnih bolesti kod osoba sa HIV/AIDS-om. Materijal i metode: Ispitivanje je obuhvatilo sve osobe inficirane HIV-om koje su se konsekutivno javile dermatovenerologu u Gradskom zavodu za kožne i venerične bolesti u Beogradu u periodu od januara
2011. do juna 2012. godine.

Rezultati: Preko $80 \%$ pacijenata bili su muškarci koji su imali seksualne odnose sa muškarcima. Najveća prevalencija zabeležena je za anogenitalne bradavice $(36,8 \%)$ i sifilis $(34,2 \%)$, a potom za folikulitis $(7,9 \%)$ i dermatofitne infekcije $(7,9 \%)$.

Diskusija i zaključak: Visoka prevalencija polno prenosivih infekcija kod pacijenata inficiranih HIVom, ukazala je na značaj edukacije o bezbednim seksualnim tehnikama, stalnoj upotrebi kondoma, posledicama polnih bolesti i rizicima transmisije rezistentnih sojeva HIV-a u ovoj populaciji.

\section{Ključne reči}

HIV; Kožne bolesti; Seksualno prenosive bolesti; Sindom stečene imunodeficijencije; Faktori rizika 